Proc. Estonian Acad. Sci. Biol. Ecol., 2005, 54, 4, 352-355

\title{
A method for preservation and mounting of Enchytraeidae (Oligochaeta, Annelida)
}

\author{
Anneke Beylich \\ IFAB Institut für Angewandte Bodenbiologie GmbH, Sodenkamp 59, D-22337 Hamburg, Germany; \\ anneke.beylich@ifab-hamburg.de \\ Received 12 October 2004, in revised form 21 February 2005
}

\begin{abstract}
A method of the fixation, staining, and mounting of enchytraeid worms is described in detail. Common problems are treated and possible variations of the method are discussed.
\end{abstract}

Key words: fixation, staining, mounting, Enchytraeidae.

\section{INTRODUCTION}

Enchytraeids have been increasingly investigated within the scope of bioindication projects and soil monitoring programmes during the last decade (Schouten et al. 1997, Graefe \& Schmelz 1999, Graefe et al. 2002, Römbke et al. 2002). Like most soil fauna groups they have to be determined to the species level for bioindication and soil evaluation purposes. There is a strong need to fix and mount enchytraeids for preservation for the following reasons:

- unknown species are found quite regularly, even in relatively well studied regions;

- some descriptions lack the desirable precision and require supplementing;

- the extent of intraspecific variation seems to be high, but has not been satisfactorily investigated so far;

- long-term monitoring programmes require the collection of reference material for future comparison.

Currently an ISO standard for the sampling of enchytraeids is being developed to harmonize field methods and extraction techniques (ISO 2005). However, the preservation of enchytraeids will not be addressed in detail in this standard. Until now, researchers have extracted information on methods from various sources 
and modified it as needed. The method presented here is based on Westheide \& Purschke (1988) and has been tested on several hundred specimens. Although it has apparently been used in other studies on enchytraeids (Koßmagk-Stephan 1985, Mellin 1988), little has been published on experiences and adjustments (Schmelz 2003).

\section{METHOD DESCRIPTION}

The method comprises fixation (steps 1 and 2), staining (steps 3 and 4), and mounting (steps 5-9).

(1) Fix living specimens in hot Bouin's Fluid ${ }^{1}\left(60-80^{\circ} \mathrm{C}\right)$. Keep them in the cooled down solution for several hours. Bouin's Fluid causes a strongly yellow colour.

(2) Transfer the specimens to ethanol (70\%) to destain them. If necessary, change alcohol repeatedly until the specimens are whitish again.

(3) Stain the specimens in boraxcarmine or paracarmine solution for 10-30 min.

(4) Differentiate (partial destaining) with acid ethanol $(70 \%$ ethanol with a few drops of concentrated hydrochloric acid, e.g. 5-10 drops acid on $100 \mathrm{~mL}$ ethanol). This treatment should result in the specimens being only slightly reddish. They should show the red pharyngeal glands (septal glands) shining through the rosy body wall. The differentiation will take a few hours to 1-2 days and should be controlled under the dissecting microscope. Keep the specimens in $70 \%$ ethanol until further treatment.

(5) Dehydrate the specimens in an ascending series: $96 \%$ ethanol $\rightarrow$ 2-propanol $(100 \%)$ or ethanol $(100 \%) \rightarrow 1: 1$ mixture of 2-propanol and xylene $\rightarrow$ xylene ( 1 hour each). If the xylene turns turbid once the specimens have been introduced, the dehydration was probably insufficient - take specimens back to fresh 2-propanol.

(6) Mix a small amount of Canada balsam with several drops of xylene until it is fluid enough to put small drops on a microscopic slide with a thin glass rod.

(7) Transfer the specimens to a Petri dish with the diluted Canada balsam.

(8) Put a few drops of Canada balsam on a microscopic slide, add the specimen, and lower the cover glass carefully upon it. Take just enough Canada balsam to produce a complete thin layer under the cover glass. With very thick specimens it might be helpful to weight the cover with a small heavy object to execute a little pressure until the Canada balsam has dried. Allow the mounting agent to harden for several hours to a few days, depending on the thickness of the specimen. The drying process can be accelerated in a drying cabinet at about $35-40^{\circ} \mathrm{C}$.

(9) Should the Canada balsam not completely fill the space under the cover glass, place a drop of it at the edge of the cover glass. It will be drawn under it by capillary forces.

1 Bouin's Fluid: saturated picric acid: formaldehyde ( 35\%): concentrated acetic acid (glacial) in a ratio $15: 5: 1$ 


\section{DISCUSSION}

Enchytraeids undergoing the mounting process should generally have been determined in a living state beforehand, as not all relevant structures can be seen in every mounted specimen. Some structures disappear completely, e.g. the granulation of the lymphocytes. Thus, specimens of similar species should not be put together in one vessel during the mounting procedure as they might prove undistinguishable when mounted.

Anesthetization of the animals is recommended prior to fixation in order to prevent contraction. In strongly contracted specimens the inner organs might not appear in the right position to each other and length measurements are not possible. Enchytraeids can be anesthetized with carbonated water (soda water), diluted beer (Healy \& Rota 1992), or by gradually adding drops of ethanol (40\%) to the water in which they are inspected (Schmelz 2003). In any case the anesthetizing solution should be removed before pouring the hot Bouin's fluid on the immobile animals.

A variation of the procedure was proposed by Schmelz (2003), who washed the specimens with an ethanol/ $\mathrm{NH}_{3}$ solution after the fixation in Bouin's Fluid and also after the differentiation with acid ethanol. In the first case this will remove a surplus of picrinic acid and thus bleach the specimen. After the differentiation the $\mathrm{NH}_{3}$ will remove superfluous $\mathrm{H}^{+}$ions, which might lead to further unwanted destaining. For the same purpose, Westheide \& Purschke (1988) employed a careful rinsing with $70 \%$ ethanol following differentiation. For the last step of the dehydration series, at least one change of the xylene after $30 \mathrm{~min}$ might be of advantage.

When transferring the enchytraeids from xylene to Canada balsam, sometimes the surface of the worms becomes nontransparent and silvery, or silvery bubbles appear inside the body. The reason is probably an incomplete mixture of xylene and Canada balsam. This problem can be overcome by strongly diluting the Canada balsam with xylene and later adding less diluted Canada balsam to the edges of the cover glass as the xylene evaporates.

\section{ACKNOWLEDGEMENTS}

Thanks are due to Rüdiger Schmelz, Ulfert Graefe, Tarmo Timm, and two anonymous referees for helpful contributions and comments to the manuscript.

\section{REFERENCES}

Graefe, U. \& Schmelz, R. M. 1999. Indicator values, strategy types and life forms of terrestrial Enchytraeidae and other microannelids. Newsl. Enchytraeidae, 6, 59-67.

Graefe, U., Elsner, D.-C., Gehrmann, J. \& Stempelmann, I. 2002. Schwellenwerte der Bodenversauerung für die Bodenbiozönose. Mitt. Dtsch. Bodenk. Ges., 98, 39-40. 
Healy, B. \& Rota, E. 1992. Methods for collecting Enchytraeidae during expeditions. Soil Biol. Biochem., 24(12), 1279-1281.

ISO/DIS 23611-3. 2005. Soil Quality - Sampling of Soil Invertebrates - Part 3: Sampling and Soil Extraction of Enchytraeids. Genéve.

Koßmagk-Stephan, K.-J. 1985. Systematik, Faunistik und Lebenszyklus mariner Oligochaeta der Nord- und Ostseeküste. Dissertation. Mathematisch-Naturwissenschaftliche Fachbereiche der Georg-August-Universität, Göttingen.

Mellin, A. 1988. Untersuchungen zur Autökologie und Funktion von Enchytraeiden, Tubificiden und Aelosomatiden (Annelida, Oligochaeta) im Ökosystem Kalkbuchenwald. Dissertation. Mathematisch-Naturwissenschaftliche Fachbereiche der Georg-August-Universität, Göttingen.

Römbke, J., Dreher, P., Beck, L., Hund-Rinke, K., Jänsch, S., Kratz, W., Pieper, S., Ruf, A., Spelda, J. \& Woas, S. 2002. Entwicklung von bodenbiologischen Bodengüteklassen für Acker- und Grünlandstandorte. UBA-Text 20/02. Umweltbundesamt, Berlin.

Schmelz, R. M. 2003. Taxonomy of Fridericia (Oligochaeta, Enchytraeidae). Revision of species with morphological and biochemical methods. Abh. naturwiss. Ver. Hamburg (NF), 38.

Schouten, A. J., Brussard, L., De Ruiter, P. C., Siepel, H. \& van Straalen, N. M. 1997. Een indicatorsysteem voor life support functies van de bodem in relatie tot biodiversiteit. Rapport nr. 712910005, Rijksinstituut voor Volksgezondheid en Milieu, Bilthoven.

Westheide, W. \& Purschke, G. 1988. Organism processing. In Introduction to the Study of Meiofauna (Higgins, R. P. \& Thiel, H., eds.), pp. 146-160. Smithsonian Institution Press, Washington DC, London.

\section{Meetod valgeliimuklaste (Oligochaeta, Annelida) fikseerimiseks ja püsipreparaatide valmistamiseks}

\section{Anneke Beylich}

On soovitatud standardmeetodit: fikseerimine kuumas Bouini vedelikus, leotamine 70\%-lises alkoholis, värvimine boorakskarmiini- või parakarmiinilahusega, diferentseerimine $70 \%$-lises alkoholis koos vähese soolhappega, säilitamine $70 \%$-lises alkoholis, dehüdratatsioon läbi alkoholirea, 2-propanooli ning ksülooli ja monteerimine lahjendatud kanada palsamisse katteklaasi alla. 